\title{
BIBLIOGRAPHY OF SCOTTISH NAME STUDIES FOR 2019
}

\author{
SIMON TAYLOR \\ University of Glasgow
}

The aim of this bibliography is to present, in a continuous list arranged alphabetically by author, all relevant articles, chapters in edited books, monographs, e-books and PhDs (most of which are now available on-line) which appeared in 2019. It is then followed by a Reviews section, and finally by a section on new digital resources.

This bibliography does not cover the shorter articles, often illustrated, on a wide range of Scottish toponymic themes which appear in Scottish Place-Name News (SPNNews), the excellent twice-yearly newsletter of the Scottish PlaceName Society [SPNS]. This publication also includes summaries of the papers given at the SPNS spring and autumn conferences. Note that all back issues, apart from the latest two, are available free on the SPNS website at: http://spns.org.uk/scottish-place-name-news.

For extensive bibliographies of name studies in Britain and Ireland and, less comprehensively, other parts of northern Europe, see the bibliographic sections in the relevant issues of Nomina, the journal of the Society for Name Studies in Britain and Ireland. The material in these Nomina bibliographies is set out thematically and includes relevant reviews which have appeared in the given year.

I would be very pleased to hear from anyone who spots any omissions or errors in the following bibliography. I can be contacted via the JSNS website and on <simon.taylor@glasgow.ac.uk> . Also, I would be glad to receive notice of anything published in 2020 for inclusion in JSNS 15 .

In order to make it easier for the reader to find their way around, I have put in bold not only authors' surnames but also some of the key places, persons or elements discussed in the individual entries.

Appended to this bibliography is a list of some recently published websites dealing with localities throughout Scotland.

I would like to thank Thomas Clancy, Carole Hough, Alan James, Peter McNiven and Eila Williamson for their help in compiling this bibliography. 
Aitchison, Nick, 2019, 'Pictish *pont 'bridge' as a place-name element: Pitpointie in its wider contexts', The Journal of Scottish Name Studies 13, 136.

Butter, Rachel, 2019, 'Saints in Names in Late Medieval Argyll: a Preliminary Enquiry', in Hammond, ed., 2019, 221-43.

Clancy, Thomas Owen, and Hammond, Matthew, 2019, 'The Romance of Names', in Hammond, ed., 2019, 166-86.

Coates, Richard, 2019, 'Fetlar', The Journal of Scottish Name Studies 13, 37-54.

Curtis, Liz, 2019, 'Two Old English Place-Names: Haddington and Clerkington', Transactions of the East Lothian Antiquarian and Field Naturalists' Society XXXII, $36-41$.

Cuthbertson, Katherine M. E., 2018, "The use of name evidence in lexicography: comparative analysis of onomastic data for historical and contemporary Scots' unpublished $\mathrm{PhD}$ thesis, University of Glasgow. https://theses.gla.ac.uk/74257/[completed 2019].

Davies, John Reuben, 2019, 'Old Testament Personal Names in Scotland before the Wars of Independence', in Hammond, ed., 2019, 187-212.

Di Clemente, Valeria, 2019, 'Masculine Given Names of Germanic Origin in the Ragman Roll (1296)', in Hammond, ed., 2019, 148-165.

Edmonds, Fiona, 2019, Gaelic Influence on the Northumbrian Kingdom. The Golden Age and the Viking Age (Woodbridge) [makes extensive use of placename evidence on both sides of the Anglo-Scottish border including the Scottish Solway littoral].

Evans, Nicholas, 2019, 'Personal Names in Early Medieval Gaelic Chronicles', in Hammond, ed., 2019, 18-40.

Given, Michael, Oscar Aldred, Kevin Grant, Peter McNiven, and Tessa Poller, 2019, 'Interdisciplinary approaches to a connected landscape: upland survey in the Northern Ochils', Proceedings of the Society of Antiquaries of Scotland 148, 83-111 [place-name contribution by Peter McNiven]. Open access on the PSAS website.

Hammond, Matthew, ed., 2019, Personal Names and Naming Practices in Medieval Scotland, Studies in Celtic History XXXIX (Woodbridge, Suffolk).

Hammond, Matthew, 2019, "The Development of Mac Surnames in the Gaelic World', in Hammond, ed., 2019, 100-43.

Hough, Carole, 2019, 'What's in a place name?', Historic Scotland (Autumn 2019), $3^{2-36 .}$ 
James, Alan, 2019, 'New Thoughts on Old Place-Names: Tyninghame and Whittingehame', Transactions of the East Lothian Antiquarian and Field Naturalists' Society XXXII, 28-35 [an edited résumé of part of his article 'Scotland's - ham and -ingham names: a reconsideration' in JSNS 4, 2010.]

Lodge, Anthony, 2019, 'The Feu Charters of Pittenweem Priory, 1532-1567', The Journal of Scottish Name Studies 13, 55-82.

King, Jacob (ed.), 2019, Scottish Gaelic Place-Names: The Collected Works of Charles M. Robertson 1864-1927 (Skye).

King, Jacob, with Liam Crouse, 2019, Gaelic in the Landscape: the Place-Names of Eriskay/A' Ghàidhlig air Aghaidh na Tìre Ainmean-àite Ėirisgeigh (Scottish Natural Heritage and Ainmean-Àite na h-Alba). This booklet is the fifth in a series of place-names booklets AÀA have written for SNH. All five booklets are free and available as PDFs on Products (ainmean-aite.scot). Hard-copy of those booklets which are still in stock can be posted out at the cost of $\mathrm{p} \& \mathrm{p}$ only.

McNiven, Peter, 2019, 'The Pictish language and place-names in and around Glen Shee', in Early Medieval Settlement in Upland Perthshire: Excavations at Lair, Glen Shee 2012-17, ed. David Strachan, David Sneddon and Richard Tipping (Glen Shee Archaeology Project), 14-16. Open access on http://archaeopress.com/ArchaeopressShop/Public/download.asp?id $=\{31 \mathrm{~F}$ oCBE1-4B70-43C8-B95B-52DA5409BAB 3\}

McNiven, Peter, 2019: see Given 2019.

Noble, Gordon, and Nicholas Evans, 2019, The King in the North: The Pictish Realms of Fortriu and Ce (Birlinn, Edinburgh) [with contributions by various, including Simon Taylor on the place-name Rhynie on p. 59]

Ó Maolalaigh, Roibeard, 2019, 'Gaelic Personal Names and Name Elements in Scottish Charters, 1093-1286', in Hammond, ed., 2019, 41-99.

Ramaeba, Goabilwe N., 2019, 'A Comparative Study of Linguistic and Social Aspects of Personal Names in Botswana and Scotland', PhD thesis, University of Glasgow, http://theses.gla.ac.uk/74387/

Sellar, David, 2019, 'Forflissa/Forbflaith/Hvarflöð', in Hammond, ed., 2019, 1447 .

Taylor, Rex, 2019, 'Street Names and National Identities: An exploratory study between Montblanc, France, and Dumfries, Scotland', The Journal of Scottish Name Studies 13, 83-90.

Taylor, Simon, 2019, see Noble and Evans 2019, above. 
Taylor, Simon, 2019, 'Bibliography of Name Studies for 2018', The Journal of Scottish Name Studies 13, 121-23.

Taylor, Simon, with Ronald MacLean and Jacob King, with photographs by Mary MacDonald, 2019, Place-Names of the Aird and Strathglass, Invernessshire (Kiltarlity Community Council).

Turpie, Tom, 2019, 'Duthac Wigmore and Ninian Wallace: Scottish Saints and Personal Names in the later Middle Ages', in Hammond, ed., 2019, 213-2O.

Wilkinson, John Garth, 2019, 'Mo-Choe Ahoy! Saintly Sightings at the Water's Edge?', The Journal of Scottish Name Studies 13, 91-114.

\section{REVIEWS}

Evemalm, Sofia, 2019, Review of King, Jacob, ed., 2019, Scottish Gaelic Placenames: The Collected Works of Charles M. Robertson 1864-1927 (Skye), in Journal of Scottish Name Studies 13, 115-18.

Cuthbertson, Katherine, 2019, Review of Puzey, Guy and Laura Kostanski, ed., 2016, Names and Naming: People, Places, Perceptions and Power (Bristol), in The Journal of Scottish Name Studies 13, 118-20.

\section{NEW DIGITAL NAME RESOURCES}

Note 1. This includes digital resources which have come online in 2020 as well as in 2019 .

Note 2. This is not a comprehensive list. However, the intention is to publish on the Scottish Place-Name Society website https://spns.org.uk an inventory of all digital place-name resources for different regions of Scotland.

\section{Early Christianity in Uist.}

One of its aims is 'to identify sites and place-names of interest for the early and medieval Christianity of Uist.' By Thomas Clancy and Sofia Evemalm. Website and database constructed by Sofia Evemalm. It also contains an edition and translation, with notes, of 'The Life of St Cainnech of Aghaboe' by Gilbert Márkus (2018).

\section{https://uistsaints.co.uk}

\section{Place-Names of Callander}

A detailed survey of the place-names of Callander by Peter McNiven 
https://www.callanderslandscape.org/wp-content/uploads/2020/o7/GaelicPlace-names-of-Callanders-Landscape-P-McNiven-June-2020 FINAL.pdf

\section{Place-Names of the Galloway Glens.}

A Database of place-names in the parishes of Balmaclellan, Balmaghie Carsphairn, Crossmichael, Dalry, Kells and Parton, by Gilbert Márkus with Thomas Clancy and Simon Taylor. Part of the Heritage Lottery Funded 'Galloway Glens Landscape Partnership', in collaboration with the University of Glasgow. Note that this website also includes a series of blog-posts by Gilbert Márkus and Thomas Clancy on individual names and elements.

https://kcb-placenames.glasgow.ac.uk/place-names/ 